\title{
Insulin-like growth factor i (igf-I) in older adults: a review
}

\section{Introduction}

Aging can be described as a dynamic and progressive process, including morphological, functional and biochemical changes, as well as psychological modifications. These changes determine the progressive loss of adaptability to the environment, causing a high tendency to vulnerability and a higher incidence of pathological processes. ${ }^{1}$ Among the inherent alterations in the aging process, it can be highlighted the deficits in balance, mobility, muscular strength, flexibility 2,3 changes in body composition, including decreased muscle mass and bone mass ${ }^{4}$ and endocrine abnormalities, such as the reduction of insulin-like growth factor I (IGF-1) serum levels. 5,6

Therefore, the aim of the present study was to review the effects of physical exercises on IGF-1 serum levels in the elderly and the possible mechanisms underlying these responses.

The circulating IGF-1 is mainly produced by the liver in response to increased growth hormone $(\mathrm{GH})$ levels, but it can also be produced in other tissues, including skeletal muscles and bones. ${ }^{7}$ The IGF-1 provides information about the rate of bone remodeling, related to bone mineral density (BMD) ${ }^{8}$ and exerts, on the bones, an anabolic effect on the osteoblasts, increasing the cellular proliferation and estimating the synthesis of the bone mineral matrix. ${ }^{9}$

The IGF-1 generates an anabolic effect on skeletal muscle, related to the preservation of lean body mass. ${ }^{10}$ Accordingly, the reduction of IGF-1 due to aging may be associated with greater susceptibility to sarcopenia and functional dependence ${ }^{11,12}$ loss of lean mass, decreased protein synthesis, increased fat mass $^{13}$ and myostatin in elderly individuals. ${ }^{14}$ Consequently, higher levels of IGF-1 are associated with improvements in physical fitness ${ }^{15}$ and lean body mass 10 , and reduced risk of heart disease ${ }^{16}$ and mortality. ${ }^{17}$

Physical exercises may influence the secretion of hormones in the elderly. ${ }^{18}$ The hormonal impact of physical exercise can help to verify the effectiveness of training programs to maintain or improve IGF1 levels and to determine the potential effects of different types of exercise on this hormone. However, the training programs presented methodological differences, such as the type of exercise used, the intensity and the volume of training. ${ }^{19-23}$

Among the different types of exercises that influenced the IGF1 serum levels in the elderly, increases of this hormone were found with strength training ${ }^{21,22,24}$ aerobic training - with aquatic exercises 22 and running, ${ }^{25}$ flexibility training ${ }^{20}$ dance ${ }^{21,26}$ and kinesiotherapy. ${ }^{27}$ The interventions ranged from two to three times per week, during three to six months.

Muscle strength training has shown higher increases in IGF-1 levels in the elderly compared to endurance training. ${ }^{22,25}$ This may improve functional autonomy ${ }^{28}$ and quality of life in aging. ${ }^{29}$

Therefore, due to the benefits of higher levels of IGF-1 in the elderly, it is suggested to extend the knowledge of means that can possibly increase the synthesis and release of this hormone. Thus,
Volume I Issue $6-2017$

\author{
Juliana Brandão Pinto de Castro,' Rodrigo \\ Gomes de Souza Vale ${ }^{1,2,3}$ \\ 'Postgraduate Program in Exercise and Sport Sciences, State \\ University of Rio de Janeiro, Brazil \\ ${ }^{2}$ Laboratory of Human Motricity Biosciences, Federal University \\ of the State of Rio de Janeiro, Brazil \\ ${ }^{3}$ Laboratory of Exercise Physiology, Estácio de Sá University, \\ Brazil
}

Correspondence: Rodrigo Gomes de Souza Vale, Department of Postgraduate Program in Exercise and Sport Sciences, Rio de Janeiro State University, Brazil, Email rodrigovale@globo.com

Received: July 01, 2017 | Published: August 07, 2017

future researches should investigate the effects on IGF-1 of different configurations of intensity and volume of training, as well as different types of exercises.

\section{Acknowledgements}

None.

\section{Conflict of interest}

Author declares there is no conflict of interest in publishing the article.

\section{References}

1. Pisciottano MV, Pinto SS, Szejnfeld VL, et al. The relationship between lean mass, muscle strength and physical ability in independent healthy elderly women from the community. $J$ Nutr Health Aging. 2010;18(5):554-558.

2. Garcia PA, Dias JMD, Dias RC, et al. A study on the relationship between muscle function, functional mobility and level of physical activity in community-dwelling elderly. Rev Bras Fisioter. 2011;15(1):15-22.

3. Locks RR, Costa TC, Koppe S, et al. Effects of strength and flexibility training on functional performance of healthy older people. Braz J Phys Ther. 2012;16(3):184-189.

4. Frontera W, Hughes V, Fielding R, et al. Aging of skeletal muscle: a 12year longitudinal study. J Appl Physiol. 2000;88(4):1321-1326.

5. Fornelli G, Isaia GC, D’Amelio P. Ageing, muscle and bone. Journal of Gerontology and Geriatrics. 2016;64(3):75-80.

6. Eliakim A, Oh Y, Cooper DM. Effect of single wrist exercise on fibroblast growth factor-2, insulin-like growth factor, and growth hormone. Am J Physiol Regul Integr Comp Physiol. 2000;279(2):R548-R553.

7. Nindl BC, Alemany JA, Tuckow AP, et al. Circulating bioactive and immunoreactive IGF-1 remain stable in women despite physical fitness improvements after 8 weeks of resistance, aerobic and combined exercise training. J Appl Physiol. 2010;109:112-120. 
8. Snow CM, Rosen CJ, Robinson TL. Serum IGF-I is higher in gymnasts than runners and predicts bone and lean mass. Med Sci Sports Exerc. 2000;32(11):1902-1907.

9. Olney RC. Regulation of bone mass by growth hormone. Med Pediatr Oncol. 2003;41(3):228-234.

10. Velloso CP. Regulation of muscle mass by growth hormone and IGF-1. Br J Pharmacol. 2008;154(3):557-568.

11. Lang T, Streeper T, Cawthon P, et al. Sarcopenia: etiology, clinical consequences, intervention, and assessment. Osteoporos Int. 2010;21(4):543-559.

12. Moran S, Chen Y, Ruthie A, et al. Alterations in IGF-1 effect elderly: role of physical activity. Eur Rev Aging Phys Act. 2007;4(2):77-84.

13. Oliveira LSC, Côrtes GG, Vale RGS, et al. Níveis séricos de IGF-1 em gerontes. Fit Perf J. 2003;2(5):289-291.

14. Baumann AP, Ibebunjo C, Grass er WA, et al. Myostatin expression in age and denervation-induced skeletal muscle atrophy. $J$ Musculoskelet Neuronal Interact. 2003;3(1):8-16.

15. Rosendahl L, Langberg H, Flyvbjerg A, et al. Physical capacity influences the response of insulin-like growth factor and its binding proteins to training. J Appl Physiol. 2002;93(5):1669-1675.

16. Juul A, Scheike T, Davidsen M, et al. Low serum insulin-like growth factor I is associated with increased risk of ischemic heart disease: a population-based case-control study. Circulation. 2002;106(8):939-944.

17. Brugts MP, Van Beld W, Hofland LJ, et al. Low circulating insulin-like growth factor-I bioactivity in elderly men is associated with increased mortality. J Clin Endocrinol Metab. 2008;93(7):2515-2522.

18. Dedeyne L, Deschodt M, Verschueren S, et al. Effects of multi-domain interventions in (pre)frail elderly on frailty, functional, and cognitive status: a systematic review. Clin Interv Aging. 2017;12:873-896.

19. Arnarson A, Geirsdottir OG, Ramel A, et al. Insulin-like growth factor-1 and resistance exercise in community dwelling old adults. J Nutr Health Aging. 2015;19(8):856-860.
20. Bastos CLB, Miranda H, Vale RGS, et al. Chronic effect of static stretching on strength performance and basal serum IGF-1 levels. $J$ Strength Cond Res. 2013;27(9):2465-2472.

21. Pires T, Dantas EHM. Comparison of the basal serum levels of IGF-1 in elderly women practitioners of weight training, dance and meditation programs at Casa do Idoso in the city of Belém-PA, Brazil. Revista de Desporto e Actividade Física. 2009;2(1):1-6.

22. Vale RGS, Oliveira RD, Pernambuco CS, et al. Effects of muscle strength and aerobic training on basal serum levels of IGF-1 and cortisol in elderly women. Arch Gerontol Geriatr. 2009;49(3):343-347.

23. Vale RGS, Oliveira RD, Pernambuco CS, et al. Correlation between basal serum IGF-1 levels and functional autonomy in elderly women. Rev Int Cienc Deporte. 2009;5(14):11-18.

24. Vale RGS, Rodrigues VF. Effects of strength training on IGF-1 and functional autonomy in eldely women. Revista Ciencias de la Actividad Física UCM. 2014;15(2):35-42.

25. Deuschle M, Blum WF, Frystyk J, et al. Endurance training and its effect upon the activity of the GH-IGFs system in the elderly. Int J Sports Med. 1998;19(4):250-254.

26. Dantas EHM, Pires T, Castro JC, et al. Serum levels of IGF-1 in elderly women engaged in various motor activities. Physical Education and Sport. 2008;52:81-83.

27. Santos LTA, Vale RGS, Mello DB, et al. Effects of kinesiotherapy on the levels of IGF-1, muscle strength and functional autonomy in older women. Rev Bras Cineantropom Desempenho Hum. 2010;12(6):451-456.

28. Pernambuco CS, Vale RG, Di Masi F, et al. Functional autonomy, bone mineral density (BMD) and serum osteocalcin levels in older female participants of an aquatic exercise program (AAG). Arch Gerontol Geriatr. 2013;56(3):466-471.

29. Borba-Pinheiro CJ, Dantas EH, Vale RG, et al. Resistance training programs on bone related variables and functional independence of postmenopausal women in pharmacological treatment: A randomized controlled trial. Arch Gerontol Geriatr. 2016; 65:36-44. 